\title{
57. DATA REPORT: GEOCHEMICAL ANALYSIS OF MULTIPLE PLANKTONIC FORAMINIFER SPECIES AT DISCRETE TIME INTERVALS ${ }^{1}$
}

\author{
Bradley N. Opdyke ${ }^{2}$ and Paul N. Pearson ${ }^{3}$
}

\begin{abstract}
Three trace elements (magnesium, strontium, and fluoride) and the stable isotopes of carbon and oxygen were measured for three distinct samples (two from the middle Miocene and one from the late Oligocene) on numerous planktonic foraminiferal species. Foraminiferal calcite measured from Leg 144 preserves a heterogeneous range of trace element contents, implying that such measurements may have value as paleocean tracers for planktonic foraminifer paleoenvironments.
\end{abstract}

\section{INTRODUCTION}

Opdyke et al. (1993) recently have suggested that the fluoride (F) content of planktonic foraminiferal calcite is sensitive to its life environment (whether it is shallow or deep dwelling), with shallower dwelling species enriched in F concentration. Concurrently, Rosenthal and Boyle (1993) have shown that the F content of the shells of planktonic foraminifers is very sensitive to partial dissolution or early diagenesis of the component calcite. This study was designed to test whether any minor element signal, specifically that of $\mathrm{F}$, would survive millions of years in the sediment column. Modern planktonic foraminifers from the tropical Pacific Ocean clearly fall into two populations in terms of their F content (Opdyke et al., 1993): the surface dwellers that are symbiont-bearing, and those nonsymbiont-bearing planktonic foraminifers that range in depth habitat from surface to deep water (which tend to record a more positive $\delta^{18} \mathrm{O}$ ). Relative differences in the depth habitats of planktonic foraminifers have been demonstrated by looking at the $\delta^{18} \mathrm{O}$ vs. $\delta^{13} \mathrm{C}$ of different species of planktonic foraminifers from sediments as old as the Eocene (e.g., Pearson et al., 1993).

Pelagic sediments from the guyot tops, although not perfect for stable isotope stratigraphy because of winnowing and perhaps drifting of foraminiferal sands (Pearson and Shackleton, this volume), have sedimentation rates high enough that discrete time intervals may be studied. Pelagic sediments from the guyots also have the advantage of being shallow, which causes them to be bathed in saturated water and become well preserved (see scanning electron microscope photographs in Isrealson et al., this volume). We have selected three discrete samples that allow us to investigate trace element variation within assemblages, at different sites with the same species (Sites 871 vs. 872 , middle Miocene) and at different times at the same site (Site 872 , late Oligocene vs. middle Miocene).

\section{METHODS}

Foraminifers were washed and sieved on a $63-\mu \mathrm{m}$ sieve at Cambridge University. In the $>250-\mu \mathrm{m}$ size fraction, about 40 individuals of the same species were picked for a single sample. The samples were ultrasonically cleaned for $15 \mathrm{~s}$ at the University of Michigan and then were crushed to a powder. Approximately $100 \mu \mathrm{g}$ of each sample was removed for stable isotopic analysis. The remaining sample,

\footnotetext{
${ }^{1}$ Haggerty, J.A., Premoli Silva, I., Rack, F., and McNutt, M.K. (Eds.), 1995. Proc. $O D P$, Sci. Results, 144: College Station, TX (Ocean Drilling Program).

2 The Australian National University, Department of Geology, Canberra ACT 0200, Australia.

${ }^{3}$ Department of Earth Sciences, University of Cambridge, Downing Street, Cambridge CB2 3EQ, United Kingdom. (Present address: Department of Geology, Wills Memorial Building, University of Bristol, Queens Road, Bristol BS8 IRJ, United Kingdom.)
}

typically $1 \mathrm{mg}$, was dissolved in $1.25 \mathrm{~cm}^{3}$ of double distilled $\mathrm{H}_{2} \mathrm{O}$ with a minimum of dilute HCL. Fluoride was analyzed on an aliquot of solution using a Dionex 4000 i series ion chromatograph (IC) by conductivity detection $( \pm 1.5 \%$ precision based on repetitive analyses of matrix-matched standards). The hydrophobic AS2 column was used with dilute $\mathrm{NaOH}$ for isocratic analysis, followed by stepwise cleanup to remove other anions. No interferences with the F peak were found. The precision of replicate analyses of a standard powder run on different days was typically $\pm 0.26 \mathrm{~F} / \mathrm{Ca} \times 1000$ (atomic ratio). Direct analysis of the remaining solution for $\mathrm{Ca}, \mathrm{Mg}$, and $\mathrm{Sr}$ was done by simultaneous inductively coupled plasma atomic emission spectroscopy (ICP-AES) using a Leeman Labs Plasma-Spec III ( $\pm 1 \%$ precision). Stable isotope analyses were performed on a Finnegan MAT 251 with a Kiel device, which allows individual reaction for each sample and provides $\delta^{18} \mathrm{O}$ values $\pm 0.004 \%$ PDB (relative to the Peedee belemnite) and $\delta^{13} \mathrm{C}$ to $\pm 0.01 \%=\mathrm{PDB}$.

\section{RESULTS}

When $\mathrm{F}$ is plotted vs. $\delta^{18} \mathrm{O}$ (Fig. 1), Sample $144-871 \mathrm{~A}-4 \mathrm{H}-4$, $59-61 \mathrm{~cm}$, shows little covariation and low concentrations $(1-3 \mathrm{~F} / \mathrm{Ca}$ $\times 10^{3}$ molar). However, the $\delta^{18} \mathrm{O}$ shows a range of approximately $1.5 \%$, similar to what is observed in the western Pacific Ocean today (Opdyke et al., 1993). The other Miocene site (Sample 144-872C-7H$6,20-22 \mathrm{~cm}$ ) has more positive $\delta^{18} \mathrm{O}$ values and less variability (Fig. 1). Fluoride at this site is higher overall $\left(2-4 \mathrm{~F} / \mathrm{Ca} \times 10^{3}\right.$ molar). The planktonic foraminiferal calcite from Sample 144-872C-16H-6, 78$80 \mathrm{~cm}$, late Oligocene in age, contains a larger range of $\mathrm{F}$ than their modern counterparts $\left(2-5.5\right.$ vs. $1-3 \mathrm{~F} / \mathrm{Ca} \times 10^{3}$ molar $)$. The $\delta^{18} \mathrm{O}$ values are typical for the late Oligocene at this site and show very little variability $(-0.55 \%$ to $-0.85 \%$ PDB) (Fig. 1; Table 1$)$.

The $\mathrm{Mg}$ contents of the planktonic foraminiferal calcite are lower, on average, than those found within the typical range of modern foraminiferal calcite. The Miocene samples range from 3 to $5(\mathrm{Mg} / \mathrm{Ca} \times$ $10^{3}$ molar), and the Oligocene sample from 4 to $5.5\left(\mathrm{Mg} / \mathrm{Ca} \times 10^{3}\right.$ molar) (Fig. 2). The $\delta^{18} \mathrm{O}$ plotted with $\delta^{13} \mathrm{C}$ for the foraminiferal calcite from the two Miocene samples show a $\delta^{13} \mathrm{C}$ range of about 1.5\% PDB, whereas the Oligocene sample has a $\delta^{13} \mathrm{C}$ variation of only about $0.6 \%$ (Fig. 3). Molar Sr/Ca ratios are consistent among all three sites (Table 1).

\section{DISCUSSION}

One of the goals of this study was to find out how long-term burial affects the trace-element signature of foraminiferal calcite. Assuming that there has been a heterogeneous mix of concentrations, as found in modern planktonic foraminifers, would we find homogenization or simply a reduction in $\mathrm{F}$ content? These data show neither. In fact, Sections $144-872 \mathrm{C}-7 \mathrm{H}-6$ and $-16 \mathrm{H}-6$ have foraminiferal species with 
Table 1. Minor element and stable isotope data from planktonic foraminifers.

\begin{tabular}{|c|c|c|c|c|c|c|}
\hline $\begin{array}{l}\text { Core, section, } \\
\text { interval }(\mathrm{cm})\end{array}$ & Species & $\mathrm{Mg} / \mathrm{Ca}$ & $\mathrm{Sr} / \mathrm{Ca}$ & $\mathrm{F} / \mathrm{Ca}$ & $\delta^{18} \mathrm{O}$ & $\delta^{13} \mathrm{C}$ \\
\hline $144-871 \mathrm{~A}-4 \mathrm{H}-4,59-61$ & $\begin{array}{l}\text { Globigerinoides ruber/subquadratus } \\
\text { Globigerinoides trilobus } \\
\text { Spheroidinellopsis kochi } \\
\text { Orbulina universa } \\
\text { Fohsella fohsi } \\
\text { Dentoglobigerina altispira } \\
\text { Dentoglobigerina altispira } \\
\text { Paragloborotalia mayeri } \\
\text { Globoquadrina dehiscens } \\
\text { Globigerinoides mitra } \\
\text { Globigerinella praesiphonifera }\end{array}$ & $\begin{array}{l}4.94 \\
4.13 \\
3.53 \\
5.08 \\
3.23 \\
3.44 \\
3.43 \\
3.05 \\
3.57 \\
4.77 \\
4.67\end{array}$ & $\begin{array}{l}1.38 \\
1.34 \\
1.31 \\
1.28 \\
1.39 \\
1.29 \\
1.21 \\
1.24 \\
1.39 \\
1.38 \\
1.28\end{array}$ & $\begin{array}{l}1.79 \\
2.70 \\
1.53 \\
1.42 \\
1.42 \\
1.00 \\
1.26 \\
0.99 \\
1.27 \\
2.48 \\
1.36\end{array}$ & $\begin{array}{l}-2.05 \\
-2.24 \\
-1.45 \\
-2.06 \\
-1.65 \\
-0.74 \\
-0.74 \\
-1.70 \\
-1.48 \\
-1.30\end{array}$ & $\begin{array}{l}2.23 \\
2.14 \\
1.93 \\
2.40 \\
1.45 \\
2.43 \\
2.43 \\
1.51 \\
1.09 \\
1.16\end{array}$ \\
\hline $144-872 \mathrm{C}-7 \mathrm{H}-6,20-22$ & $\begin{array}{l}\text { Globigerinoides ruber/subquadratus } \\
\text { Globigerinoides trilobus } \\
\text { Spheroidinellopsis kochi } \\
\text { Orbulina universa } \\
\text { Fohsella fohsi } \\
\text { Dentoglobigerina altispira } \\
\text { Dentoglobigerina altispira } \\
\text { Globoquadrina dehiscens } \\
\text { Globigerinella praesiphonifera }\end{array}$ & $\begin{array}{l}4.78 \\
3.38 \\
3.82 \\
4.84 \\
3.11 \\
3.56 \\
3.52 \\
3.48 \\
4.11\end{array}$ & $\begin{array}{l}1.28 \\
1.17 \\
1.19 \\
1.17 \\
1.40 \\
1.25 \\
1.30 \\
1.38 \\
1.21\end{array}$ & $\begin{array}{l}3.24 \\
3.84 \\
2.31 \\
2.87 \\
2.09 \\
2.33 \\
1.84 \\
2.66 \\
4.03\end{array}$ & $\begin{array}{l}-1.69 \\
-1.54 \\
-0.93 \\
-1.12 \\
-1.23 \\
-1.26 \\
-1.26 \\
-1.06 \\
-1.02\end{array}$ & $\begin{array}{l}2.23 \\
2.53 \\
2.17 \\
2.43 \\
1.76 \\
2.70 \\
2.70 \\
1.35 \\
1.51\end{array}$ \\
\hline $144-872 \mathrm{C}-16 \mathrm{H}-6,78-80$ & $\begin{array}{l}\text { Globigerina angulisuturalis } \\
\text { Globigerina ciperoensis } \\
\text { Globorotalia mayeri/nana } \\
\text { Dentoglobigerina globularis/globosa } \\
\text { Dentoglobigerina galavisi }\end{array}$ & $\begin{array}{l}5.36 \\
5.41 \\
3.69 \\
4.12 \\
4.13\end{array}$ & $\begin{array}{l}1.24 \\
1.35 \\
1.37 \\
1.33 \\
1.27\end{array}$ & $\begin{array}{l}5.44 \\
4.16 \\
2.09 \\
3.00 \\
2.26\end{array}$ & $\begin{array}{l}-0.65 \\
-0.76 \\
-0.55 \\
-0.85 \\
-0.72\end{array}$ & $\begin{array}{l}1.60 \\
1.52 \\
0.95 \\
0.95 \\
0.90\end{array}$ \\
\hline
\end{tabular}

Note: Minor element data is reported in molar ratios $\times 10^{3}$.

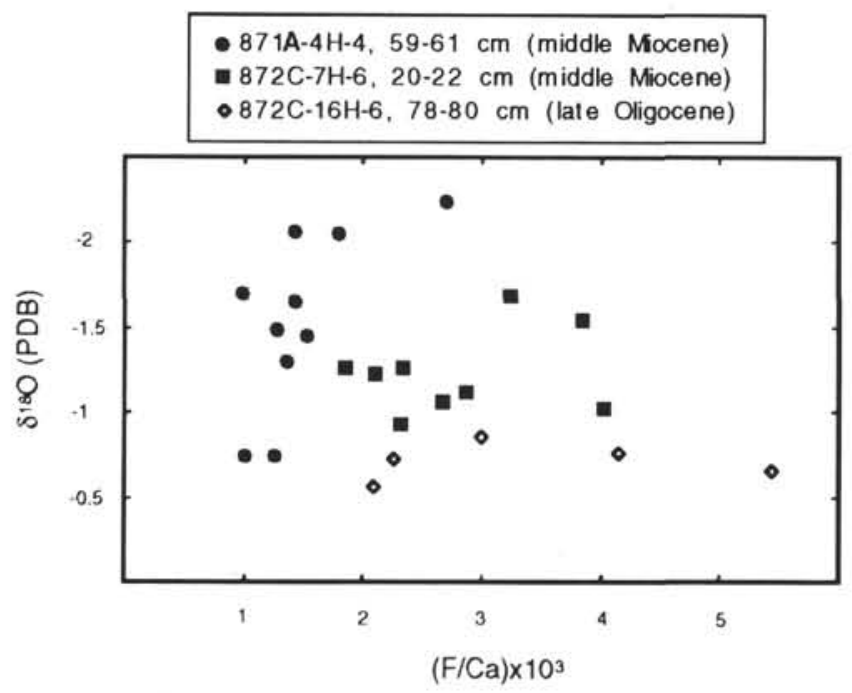

Figure 1. Molar ratios of F/Ca in foraminiferal calcite from different species vs. the $\delta^{18} \mathrm{O}$ value in PDB.

F contents higher than species found today (Fig. 1) (Opdyke et al., 1993). The $\mathrm{Mg} / \mathrm{Ca}$ ratio overall is much lower, on average, than comparable populations of modern foraminiferal calcite (modern planktonic foraminifers can have a $\mathrm{Mg} / \mathrm{Ca}$ more than $10\left[\times 10^{3}\right.$ molar $]$ ) (Fig. 2).

The relationship between $\delta^{18} \mathrm{O}$ and $\delta^{13} \mathrm{C}$ for different species of the same age can yield important information about the productivity of a region as well as the paleoecology of the foraminifers studied (Pearson et al. 1993). More positive $\delta^{13} \mathrm{C}$ of surface-dwelling foraminifers compared to deeper living species implies a more positive $\delta^{13} \mathrm{C}$ for that surface water, as a result of the sequestration of $\mathrm{C}^{12}$ caused by surface-water productivity. The Miocene samples show relatively strong $\delta^{13} \mathrm{C}$ gradients (Fig. 3), implying higher productivity

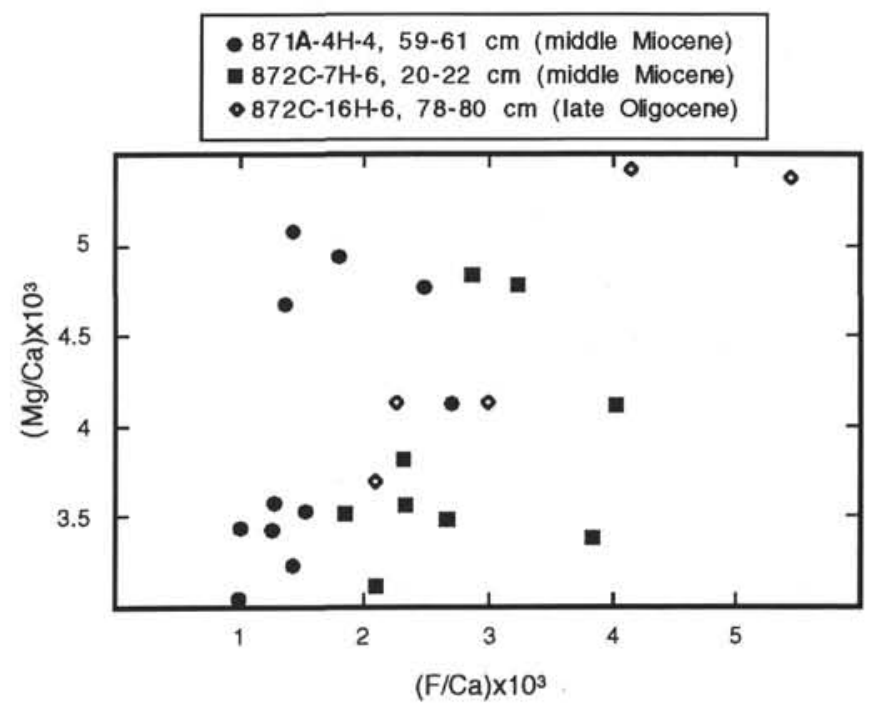

Figure 2. Molar ratio of $\mathrm{Mg} / \mathrm{Ca}$ vs. F/Ca. Fluoride contents are comparable to present values; magnesium values are relatively low.

when those sediments were deposited. This is consistent with high accumulation rates at these sites during the late Miocene (Premoli Silva, Haggerty, Rack, et al., 1993). The low $\delta^{13} \mathrm{C}$ gradient for the late Oligocene sample is typical of the $\delta^{13} \mathrm{C}$ of planktonic foraminifers for this epoch and interpreted to be the result of the low productivity (Boersma et al., 1987) (Fig. 3).

In conclusion, three main points must be considered: (1) At least some portion of the original $\mathrm{F}$ contents are preserved within these samples of planktonic foraminifers. Concentrations vary widely and are not homogenized. (2) Preliminary results from trace element analyses indicate that they successfully discriminate between species. This is a good addition to the stable isotopic analyses. (3) Fluoride clearly differentiates Oligocene species. 


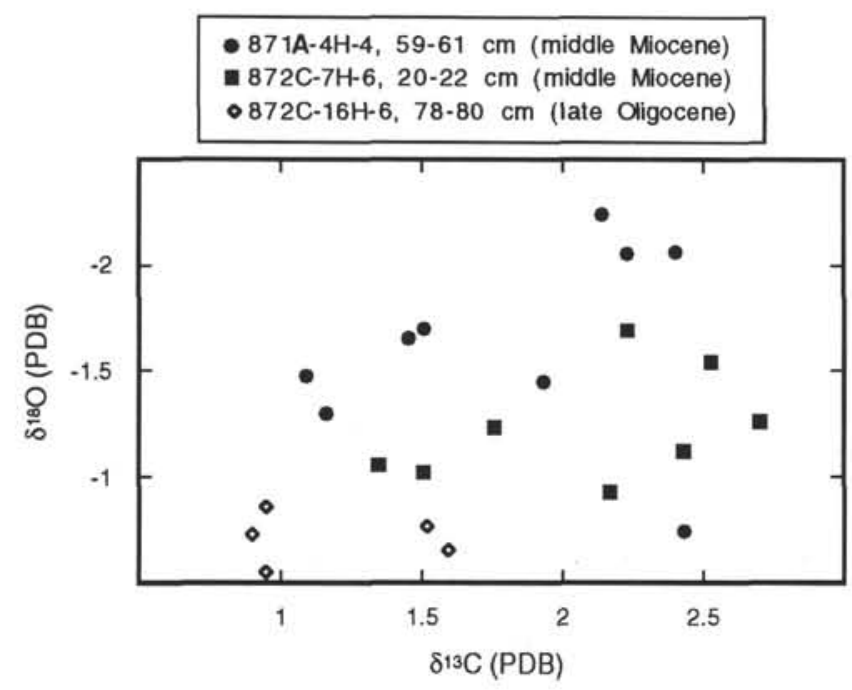

Figure $3 . \delta^{13} \mathrm{C}$ vs. $\delta^{18} \mathrm{O}$ for the samples studied. Note the difference in the range of $\delta^{13} \mathrm{C}$ between the Miocene and Oligocene samples.

\section{REFERENCES*}

Boersma, A., Premoli Silva, I., and Shackleton, N.J., 1987. Atlantic Eocene planktonic foraminiferal paleohydrographic indicators and stable isotope paleoceanography. Paleoceanography, 2:287-331.

Opdyke, B.N., Walter, L.M., and Huston, T.J., 1993. Fluoride content of foraminiferal calcite: relations to life habitat, oxygen isotope composition, and minor element chemistry. Geology, 21:169-172.

Pearson, P.N., Shackleton, N.J., and Hall, M.A., 1993. Stable isotope paleoecology of middle Eocene planktonic foraminifera and integrated isotope stratigraphy, DSDP Site 523, South Atlantic. J. Foraminiferal Res., 23:123-140.

Premoli Silva, I., Haggerty, J., Rack, F., et al., 1993. Proc. ODP, Init. Repts., 144: College Station, TX (Ocean Drilling Program).

Rosenthal, Y., and Boyle, E.A., 1993. Factors controlling the fluoride content of planktonic foraminifera: an evaluation of its paleoceanographic applicability. Geochim. Cosmochim. Acta, 57:335-346. Abbreviations for names of organizations and publications in ODP reference lists follow
the style given in Chemical Abstracts Service Source Index (published by American Chemical Society).

Date of initial receipt: 31 January 1994

Date of acceptance: 9 November 1994

Ms 144SR-052 